\title{
A NOTE ON EQUILIBRIUM UNIQUENESS IN THE BARON-FEREJOHN MODEL
}

\section{Levent Celik Bilgehan Karabay}
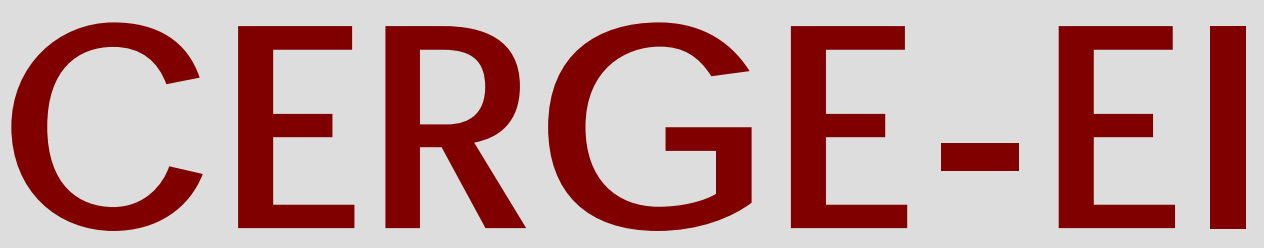

Charles University Centerfor Economic Research and Graduate Education Academy of Sciences of the Czech Republic Ec onomic Institute 


\section{Working Paper Series \\ 440 (ISSN 1211-3298)}

\section{A Note on Equilibrium Uniqueness in the Baron-Ferejohn Model}

Levent Celik

Bilgehan Karabay

CERGE-EI

Prague, May 2011 
ISBN 978-80-7343-242-3 (Univerzita Karlova. Centrum pro ekonomický výzkum a doktorské studium)

ISBN 978-80-7344-234-7 (Národohospodářský ústav AV ČR, v.v.i.) 


\title{
A Note on Equilibrium Uniqueness in the Baron-Ferejohn Model ${ }^{*}$
}

\author{
Levent Celik ${ }^{\dagger}$
}

\author{
Bilgehan Karabay
}

May 2011

\begin{abstract}
The Baron-Ferejohn multilateral bargaining model predicts a payoff-unique stationary subgame perfect equilibrium (SSPE) in which players' equilibrium strategies are not uniquely determined. In this note, we present a modified version of the Baron-Ferejohn model by introducing veto players and provide a sufficient condition to obtain a truly unique SSPE in terms of payoffs as well as players' equilibrium strategies.
\end{abstract}

\begin{abstract}
Abstrakt
Baron-Ferejohnův multilaterální vyjednávací model předpovídá jediné stacionární subgame-perfect rovnovážné řešení pro výnos (payoff-unique stationary subgame perfect equilibrium - SSPE), přičemž strategie hráčů nejsou jednoznačně určené. V této poznámce představujeme modifikovanou verzi Baron-Ferejohnova modelu tím, že zavádíme hráče s právem veta, a poskytujeme postačující podmínku pro získání skutečně jediného SSPE řešení, ve smyslu výnosu i strategie hráčů.
\end{abstract}

Keywords: Multilateral bargaining; Equilibrium uniqueness; Veto players. JEL classification codes: C72, C78.

\footnotetext{
${ }^{*}$ We would like to thank Hulya Eraslan, John Hillas, John McLaren, Robin-Eliece Mercury, Matthew Ryan and Avner Shaked for their helpful comments. This research was supported by a grant (project reference number 3625352/9554) from the University of Auckland Faculty Research Development Fund. All opinions expressed are those of the authors and have not been endorsed by the University of Auckland. All errors are our own.

CERGE-EI (a joint workplace of the Center for Economic Research and Graduate Education, Charles University, and the Economics Institute of the Academy of Sciences of the Czech Republic), P.O. Box 882, Politickych veznu 7, 111 21, Prague 1, Czech Republic. Tel: +420 224005 107. E-mail: celik@cerge-ei.cz. URL: http://home.cerge-ei.cz/celik.

Department of Economics, University of Auckland, Owen G. Glenn Building, 12 Grafton Road, Auckland 1010, New Zealand. Tel: +6499923 7193. E-mail: b.karabay@auckland.ac.nz. URL: http://bilgehan.karabay.googlepages.com.
} 


\section{Introduction}

The Baron-Ferejohn model is one of the most widely used legislative bargaining models to study different aspects of distributive politics and government policy-making. ${ }^{1}$ Despite its wide use, there are still some issues that are not clarified enough in the literature. One such issue is the uniqueness of a stationary subgame perfect equilibrium (SSPE). Eraslan (2002) states on pages 11-12 the following:

While in their [Baron-Ferejohn, 1989] model they allow for the probabilities with which the players are selected to be the proposer to differ, they only establish the uniqueness of the stationary subgame perfect equilibrium when these recognition probabilities are restricted to be the same.

Baron and Ferejohn also show with an example that when the players have different probabilities of being selected as proposer, the equilibrium need not be unique. In particular, they construct an example with a continuum of equilibria. However, in this example all the equilibria yield the same payoffs.

The multiplicity of SSPE in the asymmetric Baron-Ferejohn game that Eraslan describes arises from the flexibility to choose the randomization probabilities with which proposers select coalition members. We first argue that Eraslan's statement is not entirely true; the multiplicity of equilibria that is present in the asymmetric setup is also present in the symmetric setup, i.e., the equilibrium is not unique in the symmetric setup either. Next, we present a modified version of the Baron-Ferejohn game by introducing veto players and describe a sufficient condition for a unique SSPE.

\section{The Baron-Ferejohn game}

A $k$-majority rule symmetric Baron-Ferejohn game is an infinite-horizon sequential multilateral bargaining game with the following structure. At the beginning of each period, one of the $n$

\footnotetext{
${ }^{1}$ See Snyder, Ting and Ansolabehere (2005) and the references therein for further examples (especially footnote 6 on page 5). In addition, see Celik, Karabay and McLaren (2011a and 2011b) for its recent use in trade policy.
} 
(odd) players is randomly selected (equivalently, recognized) with equal probability $\frac{1}{n}$ to make a proposal for the division of $\$ 1$. If the proposal receives $k$ votes, $1<k<n$, it is accepted and the game ends. ${ }^{2}$ Otherwise, the game proceeds to the next period in which another player (possibly the same) is randomly selected to make a proposal. This process continues until an agreement is reached. When voting on a proposal, players compare their current payoff with the alternative of continuing to the next period. ${ }^{3}$ All players discount the future at a common rate of $\delta$.

The equilibrium concept used is stationary subgame perfect equilibrium (SSPE). In a stationary equilibrium, a player who is recognized to make a proposal in any two different periods makes the same proposal in both periods. ${ }^{4}$ Hence, stationary equilibria are historyindependent.

When selected as the proposer, a player makes a proposal that will be accepted by exactly $k$ players since she wants to maximize her own share of the dollar. In other words, she offers a positive share to only $k-1$ other players, thereby forming a minimum winning coalition. ${ }^{5}$ Let $p_{i j}$ represent the equilibrium probability that the $i^{\text {th }}$ player chooses the $j^{\text {th }}$ player as a coalition member when she is the proposer, and $x_{i j}$ represent the equilibrium share she offers to the $j^{\text {th }}$ player in this case. Note that if the $j^{\text {th }}$ player is not in the winning coalition, then she is offered a payoff of 0 . When chosen as a coalition member, the $j^{\text {th }}$ player compares the current offer $x_{i j}$ with her discounted equilibrium continuation payoff, which is given by

$$
V_{j}=\frac{1}{n}\left[x_{j j}+\sum_{i \neq j}^{n} p_{i j} x_{i j}\right] .
$$

This is the payoff the $j^{\text {th }}$ player expects to get if she votes no to the current proposal, and the bargaining is carried over to the next period. A proposer offers each player in the winning coalition a share that is equal to the discounted equilibrium continuation payoff of that player. So, when the $i^{\text {th }}$ player includes the $j^{\text {th }}$ player in the winning coalition, it follows that

$$
x_{i j}=\delta V_{j} .
$$

\footnotetext{
${ }^{2}$ When the voting rule is unanimous, i.e., when $k=n$, the Baron-Ferejohn game has a unique SSPE. Since this is obvious, we assume $k<n$ for the rest of the analysis.

${ }^{3}$ To eliminate unreasonable equilibria, weakly dominated strategies are ruled out.

${ }^{4}$ Baron and Kalai (1993) argue that stationarity is an attractive restriction since it is the "simplest" equilibrium such that it requires the fewest computations by agents.

${ }^{5}$ This follows from subgame perfection. See Baron and Ferejohn (1989) for a more elaborate discussion.
} 
Proposition 1 The set of randomization probabilities $\left\{p_{i j}\right\}$ in a k-majority rule symmetric Baron-Ferejohn game is not unique.

Proof. See the Appendix.

One solution to the symmetric Baron-Ferejohn game, for instance, has each player choosing each possible minimum winning coalition with an equal probability (this in turn implies that $\left.p_{i j}=\frac{k-1}{n-1}\right)$. Another solution involves, if we imagine players placed around a circle, each player choosing the $k-1$ players on her right with pure strategy. It is important to note that the equilibrium strategies are balanced (see Baron and Kalai, 1993); i.e., all players have an equal probability of being included in minimum winning coalitions when added up over all proposing players. (In every SSPE, the probability that player $j$ is included in a winning coalition is given by $\frac{1}{n}\left(1+\sum_{i \neq j}^{n} p_{i j}\right)=\frac{k}{n}$.)

\section{A Modified Baron-Ferejohn game}

In this section, we present a modified version of the Baron-Ferejohn game in which there are veto players who must be present in every winning coalition. Veto players are individual or collective decision-makers whose agreement is required for the change of the status quo. There is a huge literature in political science on veto players (see Tsebelis, 2002). Examples of veto players include the President, the House and the Senate in the United States and the Prime Minister and the chambers of Parliament in western European countries.

We first assume $n=3$ and $k=2$ (i.e., three-player simple majority rule game) to show the result. Then, we generalize it. Consider the standard symmetric Baron-Ferejohn framework, but now assume that the $1^{\text {st }}$ player has veto power. Then, we have the following system of equations.

When the $3^{r d}$ player is the proposer, she surely chooses the $1^{\text {st }}$ player as the coalition partner and offers a share

$$
x_{31}=\delta \frac{1}{3}\left[x_{11}+x_{21}+x_{31}\right],
$$

where the right-hand side is the discounted continuation payoff of the $1^{\text {st }}$ player. Similarly, 
when the $2^{\text {nd }}$ player is the proposer

$$
x_{21}=\delta \frac{1}{3}\left[x_{11}+x_{21}+x_{31}\right] .
$$

When the $1^{\text {st }}$ player is the proposer, on the other hand, she has a flexibility as to whom to choose as the coalition partner. Thus,

$$
\begin{aligned}
& x_{12}=\delta \frac{1}{3}\left[x_{22}+p_{12} x_{12}\right], \\
& x_{13}=\delta \frac{1}{3}\left[x_{33}+p_{13} x_{13}\right] .
\end{aligned}
$$

Since the right-hand sides of equations (3) and (4) are the same, we must have $x_{31}=x_{21}=$ $1-x_{22}=1-x_{33}$. In addition, for the $1^{\text {st }}$ player to randomize between the other two players, we must have $x_{12}=x_{13}=1-x_{11}$. Moreover, we know that $p_{12}+p_{13}=1$. To simplify the notation, let us denote $x_{11}=x$ and $x_{22}=x_{33}=y$ and $p_{12}=p$. Thus, $x_{31}=x_{21}=1-y$ and $x_{12}=x_{13}=1-x$.

Now, we can combine and rewrite equations (3), (4), (5) and (6) as

$$
\begin{aligned}
1-y & =\delta \frac{1}{3}[x+(1-y)+(1-y)] \\
1-x & =\delta \frac{1}{3}[y+p(1-x)] \\
1-x & =\delta \frac{1}{3}[y+(1-p)(1-x)] .
\end{aligned}
$$

As a result, there are three independent equations with three unknowns, and therefore, there is a unique solution. If we solve the above system, we obtain

$$
x=\frac{(3-2 \delta)(2-\delta)}{6-5 \delta}, y=\frac{(6-\delta)(1-\delta)}{6-5 \delta}, \quad p=\frac{1}{2} .
$$

How did we get a unique solution? The first thing to note is that the number of equations is always equal to the number of players, $n$. Therefore, in order to get a unique solution, the number of unknowns should not be more than $n$. For an $n$-player game, when $s<n$ of the players have veto power (i.e., they have to be in any winning coalition), there are $(n-s)$ randomization probabilities to be determined for each veto player and $(n-s-1)$ for each one of the remaining players. The randomization probabilities add up to a certain constant for each player, providing one degree of freedom. Additionally, the share veto players get, $x$, and the share other players get, $y$, need to be determined. Thus, the total number of unknowns is 
$s(n-s-1)+(n-s)(n-s-2)+2$. In order to have the number of unknowns equal to the number of equations, we must have

$$
\begin{gathered}
s(n-s-1)+(n-s)(n-s-2)+2=n, \\
\Rightarrow s=n-2 .
\end{gathered}
$$

Thus, we have the following proposition.

Proposition 2 A k-majority rule symmetric Baron-Ferejohn game has a truly unique SSPE when $k=n-1$ and there are at least $s=n-2$ veto players.

For example, for the case $n=3$ and $k=2$, it is enough to have one veto player to obtain a unique SSPE. In this case, if the veto player is selected as the proposer, she chooses one of the remaining two players with equal probabilities (i.e., $p=\frac{1}{2}$ ). 


\section{Appendix}

Proof of Proposition 1. Two observations are important for the proof. First, $\sum_{j=1}^{n} V_{j}=1$, i.e., the equilibrium continuation payoffs of the players must add up to the total size of the dollar.

This can be seen analytically by summing equation (1) over $j$ :

$$
\sum_{j=1}^{n} V_{j}=\frac{1}{n}\left[\sum_{j=1}^{n} x_{j j}+\sum_{j=1}^{n} \sum_{i \neq j}^{n} p_{i j} x_{i j}\right]
$$

Note that

$$
\sum_{j=1}^{n} \sum_{i \neq j}^{n} p_{i j} x_{i j}=\sum_{j=1}^{n} \sum_{i \neq j}^{n} p_{j i} x_{j i}
$$

so $\sum_{j=1}^{n} V_{j}$ can be rewritten as

$$
\sum_{j=1}^{n} V_{j}=\frac{1}{n}\left[\sum_{j=1}^{n}\left(x_{j j}+\sum_{i \neq j}^{n} p_{j i} x_{j i}\right)\right]
$$

Since $x_{j j}+\sum_{i \neq j}^{n} p_{j i} x_{j i}$ is equal to the total size of the dollar, we have

$$
\sum_{j=1}^{n} V_{j}=\frac{1}{n}\left[\sum_{j=1}^{n} 1\right]=1
$$

Second, since all players are symmetric, their equilibrium continuation payoffs must be equal. ${ }^{6}$ This implies $V_{j}=\frac{1}{n}$ for all $j=1, \ldots, n$. As a result, each player is always offered the same share whenever she is in a winning coalition (except for when she is the proposer). Similarly, the share the proposer gets is also the same for all players who are proposers:

$$
\begin{gathered}
x_{i i}=x \text { for all } i=1, \ldots, n, \\
x_{i j}=\frac{1-x}{k-1} \text { for all } i \neq j .
\end{gathered}
$$

\footnotetext{
${ }^{6}$ Here, we provide a formal proof for $n=3$. The main logic extends to any value of $n$. Without a loss of generality, order the continuation values such that $V_{1} \leq V_{2} \leq V_{3}$. First, suppose that $V_{3}>V_{2}$. By equation (7), this implies that $V_{3}>\frac{1}{3}$. Since player 3 has the highest continuation value, she is in a winning coalition only when she is the proposer. This means that $V_{3}=\frac{1}{3} x_{33}$. Since $x_{33} \leq 1$, we reach a contradiction. Hence, $V_{2}=V_{3}$. Next, suppose $V_{1}<V_{2}$, which implies that $V_{1}<\frac{1}{3}$. In this case, player 1 is always in the winning coalition. When she is the proposer, she offers a payoff of $\delta V_{2}$ to one of the other two players. When one of the other two players is the proposer, she is offered a payoff of $\delta V_{1}$. Thus, $V_{1}=\frac{2}{3} \delta V_{1}+\frac{1}{3}\left(1-\delta V_{2}\right)$. By equation (7) and the fact that $V_{2}=V_{3}$, we have $V_{2}=\frac{1-V_{1}}{2}$. Plugging this into the previous expression, we have $V_{1}=\frac{2}{3} \delta V_{1}+\frac{1}{3}\left(1-\delta \frac{1-V_{1}}{2}\right)$. Simplifying leads to $V_{1}=\frac{2-\delta}{6-5 \delta} \geq \frac{1}{3}$, so again a contradiction. Hence, it must be true that $V_{1}=V_{2}=V_{3}$.
} 
Then, by using equations (1) and (8), we can rewrite equation (2) as

$$
\frac{1-x}{k-1}=\frac{\delta}{n}\left[x+\frac{1-x}{k-1} \sum_{i \neq j}^{n} p_{i j}\right] \text { for all } j=1, \ldots, n \text {. }
$$

As a result, we have $n(n-1)$ randomization probabilities together with $x$ to be determined. It is possible to reduce the number of unknown variables. First, since $V_{j}=\frac{1}{n}$, the term in the brackets in equation (9) must be equal to 1 . Hence,

$$
\sum_{i \neq j}^{n} p_{i j}=k-1 \text { for all } j=1, \ldots, n .
$$

This further implies that it is possible to determine $x$ uniquely. Given that $V_{j}=\frac{1}{n}$ for all $j$, equation (9) implies

$$
\begin{gathered}
x_{i i}=x=1-(k-1) \frac{\delta}{n}, \\
x_{i j}=\frac{\delta}{n} \text { for all } i \neq j .
\end{gathered}
$$

In addition, notice that there is a total of $\frac{(n-1) !}{(k-1) !(n-k) !}$ possible coalitions the $i^{t h}$ player may form when she is the proposer. All of these possibilities occur with certain probabilities which add up to 1 . The probability that the $j^{\text {th }}$ player $(j \neq i)$ is in the winning coalition, $p_{i j}$, is simply the summation of the probabilities of the possible coalition formations to which this particular player belongs. Since all coalitions involve $k-1$ members other than the proposer, the probability assigned to a particular coalition appears $k-1$ times in the summation of the randomization probabilities, $\sum_{j \neq i}^{n} p_{i j}$. Thus, the randomization probabilities with which a player chooses coalition members add up to $k-1$, i.e.,

$$
\sum_{j \neq i}^{n} p_{i j}=k-1 \text { for all } i=1, . ., n .^{7}
$$

By making use of (10), we gain one degree of freedom for each $i$. Hence, we need to determine only $n(n-2)$ randomization probabilities along with $x$, or $n(n-2)+1=(n-1)^{2}$

\footnotetext{
${ }^{7}$ An example may be helpful. Consider a 5-player game with $k=3$, and assume that player 1 is the proposer. There are 6 possible coalitions that player 1 may form: $C_{1}=\{1,2,3\}, C_{2}=\{1,2,4\}, C_{3}=\{1,2,5\}, C_{4}=$ $\{1,3,4\}, C_{5}=\{1,3,5\}$ and $C_{6}=\{1,4,5\}$, where the elements indicate the identities of players. Let $q_{i}$ denote the probability that $C_{i}$ occurs. Note that $\sum_{i=1}^{6} q_{i}=1$. Then, we have: $p_{12}=q_{1}+q_{2}+q_{3}, p_{13}=q_{1}+q_{4}+q_{5}$, $p_{14}=q_{2}+q_{4}+q_{6}$ and $p_{15}=q_{3}+q_{5}+q_{6}$. This implies that $\sum_{j=2}^{5} p_{1 j}=2\left(q_{1}+q_{2}+q_{3}+q_{4}+q_{5}+q_{6}\right)=2$.
} 
unknowns in total. However, there are only $n$ independent equations given by (9). Thus, for any $n \geq 3$, the solution to randomization probabilities is not unique. 


\section{References}

[1] Baron, D. P. and J. A. Ferejohn, 1987. Bargaining and agenda formation in legislatures. American Economic Review Papers and Proceedings 77, pp. 303-309.

[2] Baron, D. P. and J. A. Ferejohn, 1989. Bargaining in legislatures. American Political Science Review 83, pp. 1181-1206.

[3] Baron, D.P. and E. Kalai, 1993. The simplest equilibrium of a majority-rule division game. Journal of Economic Theory 61, pp. 290-301.

[4] Celik, L., B. Karabay and J. McLaren, 2011a. Trade policy-making in a model of legislative bargaining. Mimeo, CERGE-EI, University of Auckland and University of Virginia.

[5] Celik, L., B. Karabay and J. McLaren, 2011b. When is it optimal to delegate? The theory of fast-track authority. Mimeo, CERGE-EI, University of Auckland and University of Virginia.

[6] Eraslan, H., 2002. Uniqueness of stationary equilibrium payoffs in the Baron-Ferejohn model. Journal of Economic Theory 103, pp. 11-30.

[7] Snyder, J., M. Ting and S. Ansolabehere, 2005. Legislative bargaining under weighted voting. American Economic Review 95, pp. 981-1004.

[8] Tsebelis, G., 2002. Veto Players: How Political Institutions Work. Cambridge, MA: MIT Press. 


\section{Working Paper Series}

ISSN 1211-3298

Registration No. (Ministry of Culture): E 19443

Individual researchers, as well as the on-line and printed versions of the CERGE-EI Working Papers (including their dissemination) were supported from the following institutional grants:

- Economic Aspects of EU and EMU Entry [Ekonomické aspekty vstupu do Evropské unie a Evropské měnové unie], No. AVOZ70850503, (2005-2011);

- Economic Impact of European Integration on the Czech Republic [Ekonomické dopady evropské integrace na ČR], No. MSM0021620846, (2005-2011);

Specific research support and/or other grants the researchers/publications benefited from are acknowledged at the beginning of the Paper.

(c) Levent Celik and Bilgehan Karabay, 2011

All rights reserved. No part of this publication may be reproduced, stored in a retrieval system or transmitted in any form or by any means, electronic, mechanical or photocopying, recording, or otherwise without the prior permission of the publisher.

Published by

Charles University in Prague, Center for Economic Research and Graduate Education (CERGE) and

Economics Institute ASCR, v. v. i. (EI)

CERGE-El, Politických vězňu 7, 11121 Prague 1, tel.: +420 224005 153, Czech Republic.

Printed by CERGE-EI, Prague

Subscription: CERGE-EI homepage: http://www.cerge-ei.cz

Phone: + 420224005153

Email: office@cerge-ei.cz

Web: http://www.cerge-ei.cz

Editor: Michal Kejak

Editorial board: Jan Kmenta, Randall Filer, Petr Zemčík

The paper is available online at http://www.cerge-ei.cz/publications/working_papers/.

ISBN 978-80-7343-242-3 (Univerzita Karlova. Centrum pro ekonomický výzkum a doktorské studium)

ISBN 978-80-7344-234-7 (Národohospodářský ústav AV ČR, v. v. i.) 
CERGE-EI

P.O.BOX 882

Politických vězňů 7

11121 Praha 1

Czech Republic http://www.cerge-ei.cz 